ISSN 1392-0340 (Print)

ISSN 2029-0551 (Online)

https://doi.org/10.15823/p.2021.141.3

Pedagogika / Pedagogy

2021, t. 141, Nr. 1 p. 53-78 / Vol. 141, No. 1, pp. 53-78, 2021

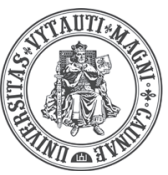

\title{
Thinking Level in Education: A Complete Revision of Anderson's Taxonomy
}

\author{
Ilmi Zajuli Ichsan ${ }^{1 *}$, Henita Rahmayanti ${ }^{2}$, Agung Purwanto ${ }^{3}$, Diana Vivanti Sigit ${ }^{4}$, \\ Edi Kurniawan ${ }^{5}$, Ardyanto Tanjung ${ }^{6}$, Ruqiah Ganda Putri Panjaitan ${ }^{7}$, Nurlita Pertiwi ${ }^{8}$, \\ Charanjit Kaur Swaran Singh'
}

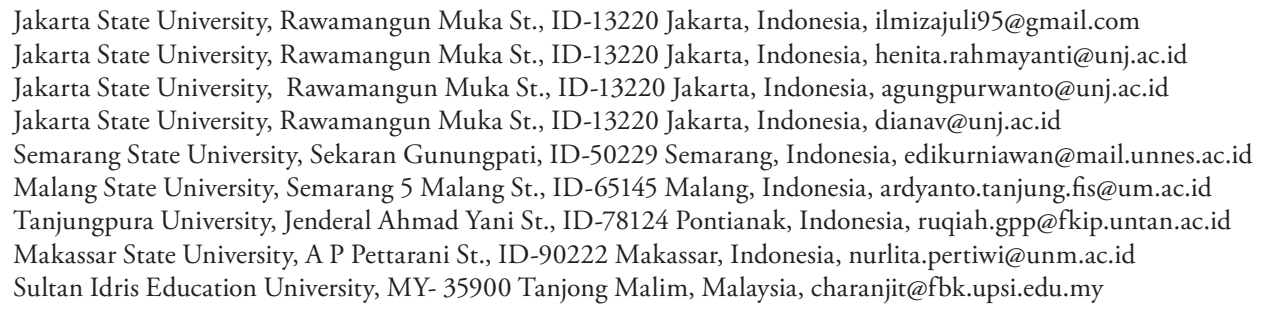

Annotation. The study aimed to revise Anderson's taxonomy and implement the new taxonomy in learning. The study used the descriptive method and there were 6 types of instruments used according to new taxonomy. The results showed that students' knowledge scores were still in a very low category at the Natural science, Environment, and Social Science at School and University levels. This study concluded that a new taxonomy had been developed and its implementation indicated that students' knowledge score was still very low.

Keywords: education, new taxonomy, thinking level.

\section{Introduction}

21 st century education has changed in various aspects. The changes include technology used in learning up to abilities must be acquired by students. This happens to adapt to the needs of various fields of work and expertise in the 21st century. Students in the 21st century do not only need memory ability but they must be able to identify and have a higher-level problem-solving skill. These abilities must certainly be taught in education (Motallebzadeh et al., 2018; Talmi et al., 2018; Zohar \& Agmon, 2018). 
One of benchmarks for a student in education is knowledge that is measured according to Thinking Level (TL). Students can find out their abilities by taking measurements according to taxonomy. One of the popular concepts is a taxonomy by Anderson et al. (2001).The taxonomy of thinking proposed by Anderson et al. (2001) consists of 6 levels: namely (1) remember, (2) understand, (3) apply, (4) analyze, (5) evaluate, and (6) create. The level of thinking expressed by Anderson et al. (2001) is also referred as cognitive process. This level of thinking is considered less relevant in 2020 due to higher thinking skills required. In the current era, the use of information technology such as smartphones and laptops has been immense. This had an impact on the tremendous flow of information received by students from various websites and other online sources (Jiang et al., 2017; Rahmayanti et al., 2020; Reyna et al., 2018, 2019; Yusop \& Sumari, 2013).

Changes in taxonomy in education become momentous, as an update according to 21 st century demands is necessary. The changes are a necessity so that students could adapt to undergoing a variety of jobs in the era of industrial revolution 4.0 that requires various skills. The previous taxonomy by Bloom (1956) indicates six levels, namely knowledge, comprehension, application, analysis, synthesis, and evaluation. These six levels aim to accommodate different needs of student's various skills in 20 th century. The demand for various skills in the 21st century surely becomes more specific and varied over time. It encourages taxonomy revision by Anderson et al. (2001) and Marzano \& Kendall (2006). The changes by Anderson include changing the thinking levels in Bloom's taxonomy that uses noun into verb. As mentioned in the previous paragraph, Anderson et al. (2001) also divides thinking level into six levels, i.e. remember, understand, apply, analyze, evaluate, and create. Moreover, Marzano revises the taxonomy by making the level thinking more specific and adding them. The thinking levels according to Marzano \& Kendall (2006) consist of Retrieval, Comprehension, Analysis, Knowledge Utilization, Metacognitive system, and self-system. The revision of taxonomy is required due to the need to improve students' demand of the 21st century skills, namely Critical Thinking, Creative Thinking, communication, and collaboration.

Previous research has carried out various revisions to Anderson's taxonomy. The revisions include the HOTSHOT taxonomy which is used to measure higher-order thinking skills (Beckwith, 2019). Recent research that has been done regarding Anderson's taxonomy revision is related to the Higher Order Thinking Skills of Environmental Problem (HOTSEP) Taxonomy developed for environmental learning (Ichsan \& Rahmayanti, 2020). HOTSEP research, a new revised thinking level from Anderson's Taxonomy, has been carried out. The HOTSEP research, however, only revised the Higher Order Thinking Skills (HOTS) domain and did not make any revisions to the Lower Order Thinking Skills (LOTS) domain. Moreover, suggestions from the HOTSEP research are to complete the Anderson's taxonomy revisions in the LOTS domain and revise all subjects/topics.

Education systems play an important role to develop critical thinking dispositions of students which is crucial to prepare them to face educational environment challenges 
(Miarsyah et al., 2019; Morganti et al., 2017; Purwanto et al., 2020; Rahmayanti et al., 2020; Sigit et al., 2019, 2020; So et al., 2019). Schools, higher education institutions, and teacher training sectors have equal roles to nurture the development of thinking skills among students. Teaching higher order thinking skills become meaningful when there is an incorporation of critical and creative thinking in activities prepared for the students. Activities prepared by educators help to guide and teach the students to think critically and analytically. Tanujaya (2016) developed an instrument that measures higher order thinking skills among students. The instrument aimed to measure students' mastery of higher-order thinking at every level of education. The study findings showed that students were not able to understand and master higher-order thinking skills. This was due to the fact that students failed to structure thinking skills. The higher-order thinking skills are a crucial aspect of the teaching and learning process. There is a dire need to develop strategies to foster higher-order thinking skills by the teachers to the students so that they can delve into in-depth understanding of cognitive development and systems of classifying thought processes. The low level of the skill is the result of teacher's lack of attention to such thinking skills (Tanujaya, 2016). For students to master thinking skills, teachers must incorporate thinking skills exercises in all subjects taught. Students with the skill of applying higher order thinking skills are able to perform with excellence. Undoubtedly, teachers must be aware of the importance of infusing HOTS for students to be able to perform with distinction. Therefore, teachers can effectively promote higher order thinking if they have an in-depth understanding of the stages of cognitive development.

Based on this description, it is urgent to carry out a comprehensive and complete revision of Anderson's Taxonomy. The new taxonomy can be used for all subjects at school or university level. Furthermore, the new taxonomy can be used for the wider community in the context of social education. This research will revise the thinking level of Anderson's taxonomy as a whole in the LOTS and HOTS domains to be used in all subjects. The new taxonomy is a novelty in the 21 st century education and is imperative to carry out. This is because the new taxonomy is more contextual to measure the ability of students in education in a rapidly developing technological era in the 21st century. Therefore, this study aimed to revise the Anderson's taxonomy to a new taxonomy and implement it in classroom learning.

\section{Method}

\section{Research design}

This study used a descriptive method with a survey technique. Descriptive research is a method that facilitates the researchers to describe in detail each score obtained by students. This will simplify the descriptive data analysis. Descriptive research is 
conducted to measure a variable in more detail (Ichsan et al., 2019; Rahmayanti et al., 2019). Research using descriptive methods is usually carried out using instruments in the form of test questions, observation sheets, interviews, or questionnaires given to respondents (Bigirwa et al., 2020; Bilasa \& Taspinar, 2020; Bodzin et al., 2020). The advantage of descriptive research is that the data collected will be more accurate because it focuses on describing the data.

\section{Sample and Data collection}

The study samples were taken from various cities in Indonesia. Samples were selected randomly using simple random sampling. The number of sample was 1030 people that comprised 334 university students, 211 Junior High School (JHS) students, and 485 Senior High School (SHS) students. Samples were randomly selected from various schools and universities in various cities in Indonesia.

\section{Analyzing Data}

The data analyzed were in the form of descriptive data. The data were analyzed using Microsoft Excel and Statistical Package for the Social Sciences (SPSS). The data presented in tabular form to make it easier to describe students' knowledge scores for each level. This was intended so that the details of each item and indicator can be described clearly. The categorization of the students' knowledge scores is presented in Table 1.

\section{Table 1}

Interval Scores and Categories of Student Knowledge

\begin{tabular}{ll}
\hline \multicolumn{1}{c}{ Category } & \multicolumn{1}{c}{ Interval of LOTS and HOTS Score } \\
\hline Very high & $\mathrm{X}>81.28$ \\
High & $70.64<\mathrm{X} \leq 81.28$ \\
Moderate & $49.36<\mathrm{X} \leq 70.64$ \\
Low & $38.72<\mathrm{X} \leq 49.36$ \\
Very low & $\mathrm{X} \leq 38.72$ \\
\hline Source: Category and interval score adapted from Ichsan et al. (2019)
\end{tabular}

\section{Thinking Level and Indicators}

The thinking levels developed in the study were in accordance with previous findings, six thinking levels were formulated as a new taxonomy in this research, namely: Identify, Compare, Implement, Criticize Problem, Solve Problem, and Develop innovation (see Table 2). Indicators used in this study were the developed knowledge indicators. The indicators were based on the revised thinking level (new taxonomy). As for the new thinking level (TL) that has been revised from the old version consisted of (TL-1) Identify, (TL-2) Compare, (TL-3) Implement, (TL-4) Criticize problem, (TL-5) Solve Problem, and (TL-6) 
develop innovation. Detail comparison of the thinking level between Anderson's version and the revised version (new taxonomy) is described in Table 2 .

Table 2

Comparison of Anderson's Taxonomy and New Taxonomy

\begin{tabular}{clll}
\hline \multicolumn{1}{c}{ Thinking Level } & Anderson's Taxonomy & New Taxonomy & Thinking Category \\
\hline Thinking Level 6 (TL-6) & Create & Develop Innovation & HOTS \\
Thinking Level 5 (TL-5) & Evaluate & Solve Problem & HOTS \\
Thinking Level 4 (TL-4) & Analyze & Criticize Problem & HOTS \\
Thinking Level 3 (TL-3) & Apply & Implement & LOTS \\
Thinking Level 2 (TL-2) & Understand & Compare & LOTS \\
Thinking Level 1 (TL-1) & Remember & Identify & LOTS \\
\hline
\end{tabular}

The changes from the Anderson's taxonomy are depicted in a diagram in Figure 1. It could be seen that there were changes in the LOTS and HOTS. There was a cross (an increase and decrease in levels in the HOTS domain) which was adapted from previous HOTSEP research (Ichsan \& Rahmayanti, 2020)especially to solve environmental problems when COVID-19 pandemic. This was to develop a new level of thinking, namely Higher Order Thinking Skills of Environmental Problem (HOTSEP). In the HOTSEP's research, three thinking levels had been revised: criticize environmental problem, solve environmental problem, and develop innovation about the environment. All revisions made to HOTSEP research were in the higher thinking level. The results of the HOTSEP study were adapted and became a thinking level in the new taxonomy in this study, namely criticize problem, solve problem, and develop innovation (see Figure 1).

As regards knowledge measurement using the new taxonomy, the instruments used were test questions in the form of multiple-choice, filling in, essays, or other forms that were still relevant to measuring student knowledge. To facilitate the preparation of test questions, the study also developed operational verbs. The function of these operational verbs is to distinguish the characteristics of each question made at various levels. The operational verbs can be modified according to the context of the learning being carried out. Details of the operational verbs can be seen in Table 3. 


\section{Figure 1}

Changes in Taxonomy from the LOTS and HOTS domains

HOTS

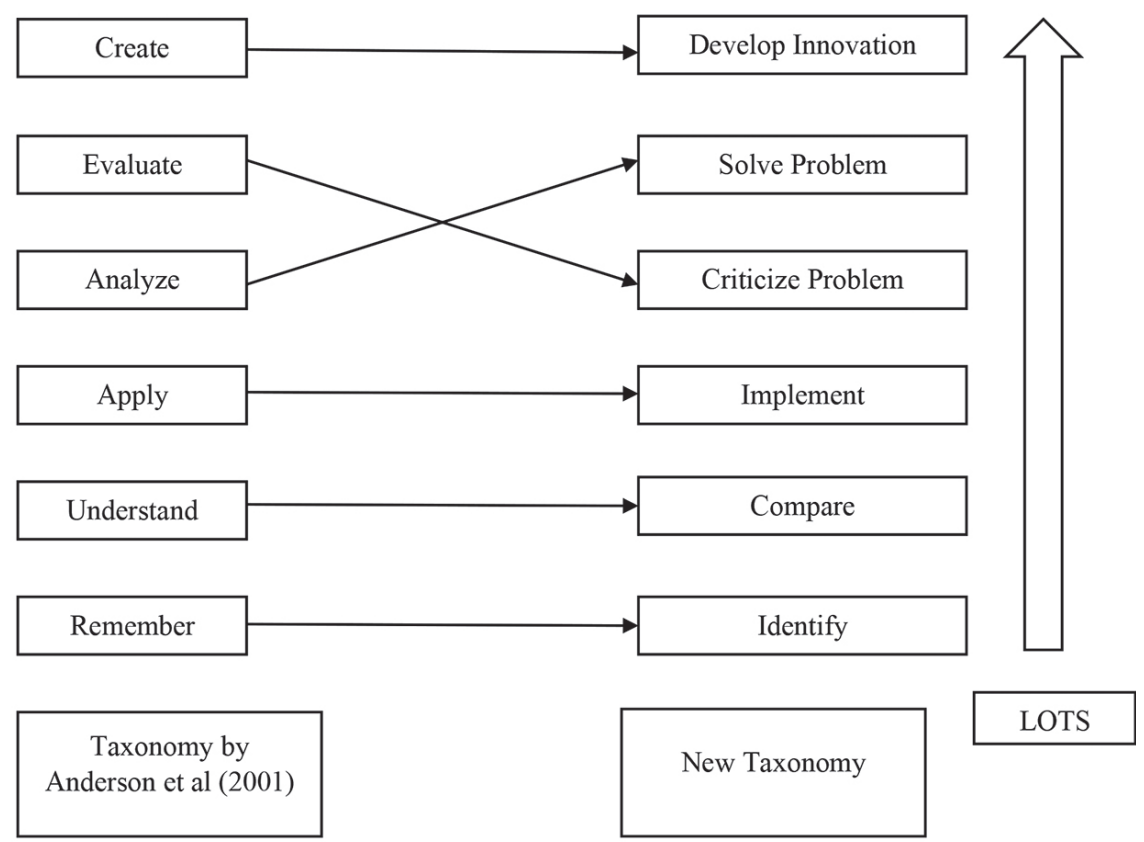

Table 3

Operational Verbs in the New Taxonomy

\begin{tabular}{lll}
\hline Thinking Level Code & $\begin{array}{c}\text { Thinking Level in New } \\
\text { Taxonomy }\end{array}$ & \multicolumn{1}{c}{ Operational Verb } \\
\hline TL-6 & Develop Innovation & - Developing a program \\
& & - Making innovation \\
TL-5 & - Writing an idea \\
& & - Solving problem \\
& & - Making a Problem Solution \\
TL-4 & Criticize Problem & - Mapping the problem solution \\
& & - Giviticizing the problem \\
& & - Giving critical opinion \\
TL-3 & - Implementing program
\end{tabular}




\section{Thinking Level Code Thinking Level in New

Taxonomy

TL-2 Compare

TL-1 Identify

\section{Operational Verb}

- Comparing

- Explaining the different

- Grouping the different

- Identifying

- Mentioning

- Marking

Note: Researchers/lecturer/teacher can use this thinking level for measuring knowledge. Thinking level cannot be modified, but operational verbs (in the table above) can be modified according to their synonyms or words with the same meaning.

\section{Instruments}

The instruments used were distributed online using Google Form. The instruments used in the study consisted of six types, namely: Environmental Knowledge for University (EKU), Natural Science Knowledge for University (NSKU), Social Science Knowledge for University (SSKU), Environmental Knowledge for School (EKS), Natural Science Knowledge for School (NSKS), and Social Science Knowledge for School (SSKS). The six instruments were developed based on the thinking level in the new taxonomy. The number of items for each instrument was 12 items. The EKU instrument is elaborated in Table 4.

\section{Table 4}

Indicators of the EKU instrument

\begin{tabular}{|c|c|c|}
\hline Thinking level & Indicator & Item \\
\hline Identify (TL-1) & Identifying various types of environmental disasters. & 1,2 \\
\hline Compare (TL-2) & $\begin{array}{l}\text { Comparing the different characteristics of natural and } \\
\text { non-natural disasters in the environment. }\end{array}$ & 3,4 \\
\hline Implement (TL-3) & $\begin{array}{l}\text { Implementing the concept of disaster for disaster } \\
\text { mitigation. }\end{array}$ & 5,6 \\
\hline Criticize problem (TL-4) & $\begin{array}{l}\text { Criticizing various community behaviors that will cause } \\
\text { environmental disasters. }\end{array}$ & 7,8 \\
\hline Solve Problem (TL-5) & $\begin{array}{l}\text { Solving environmental disaster problems by providing } \\
\text { solutions. }\end{array}$ & 9,10 \\
\hline Develop Innovation (TL-6) & $\begin{array}{l}\text { Developing innovations to solve problems in support of } \\
\text { environmental disaster mitigation programs. }\end{array}$ & 11,12 \\
\hline
\end{tabular}

Details of the NSKU instrument can be seen in Table 5. The NSKU instrument was developed with general knowledge coverage for all students. Items made are relatively more general that various students from various backgrounds can answer them. 
Table 5

Indicators from the NSKU instrument

\begin{tabular}{llc}
\hline \multicolumn{1}{c}{ Thinking level } & \multicolumn{1}{c}{ Indicator } & Item \\
\hline Identify (TL-1) & $\begin{array}{l}\text { Identifying various physical and chemical factors that } \\
\text { affect human, animal, and plants. }\end{array}$ & 1,2 \\
Compare (TL-2) & $\begin{array}{l}\text { Comparing the differences between physical and chemi- } \\
\text { cal factors in human, animal, and plants. }\end{array}$ & 3,4 \\
Implement (TL-3) & $\begin{array}{l}\text { Implementing physics and chemistry concepts in every- } \\
\text { day life related to human, animal, and plants. }\end{array}$ & 5,6 \\
Criticize problem (TL-4) & $\begin{array}{l}\text { Criticizing various technologies developed based on } \\
\text { physics, chemistry, and biology. }\end{array}$ & 7,8 \\
Solve Problem (TL-5) & $\begin{array}{l}\text { Solving problems around them using the concepts of } \\
\text { physics, chemistry, and biology. }\end{array}$ & 9,10 \\
Develop Innovation (TL-6) & $\begin{array}{l}\text { Developing innovations to solve problems and support } \\
\text { efforts to conserve nature based on various concepts of } \\
\text { physics, chemistry, and biology. }\end{array}$ & 11,12 \\
\hline
\end{tabular}

The SSKU instrument made for the university level focuses more on the overall concept of social sciences from the aspects of geography, sociology, and economics. These various aspects were included to measure student knowledge. In more detail, the indicators for this instrument can be seen in Table 6 .

Table 6

Indicators of the SSKU Instrument

\begin{tabular}{llc}
\hline \multicolumn{1}{c}{ Thinking level } & \multicolumn{1}{c}{ Indicator } & Item \\
\hline Identify (TL-1) & $\begin{array}{l}\text { Identifying various social events that occur in the } \\
\text { community. }\end{array}$ & 1,2 \\
Compare (TL-2) & $\begin{array}{l}\text { Comparing the differences between social, economic } \\
\text { and geographic factors in a society. }\end{array}$ & 3,4 \\
Implement (TL-3) & $\begin{array}{l}\text { Implementing the concepts of sociology, economics, } \\
\text { and geography that have been studied. }\end{array}$ & 5,6 \\
Criticize problem (TL-4) & $\begin{array}{l}\text { Criticizing various social and economic problems } \\
\text { caused by geographic factors. }\end{array}$ & 7,8 \\
Solve Problem (TL-5) & $\begin{array}{l}\text { Solving problems around them using the concepts of } \\
\text { economics, sociology, and geography that have been } \\
\text { studied. }\end{array}$ & 9,10 \\
Develop Innovation (TL-6) & $\begin{array}{l}\text { Developing innovations to solve social problems with } \\
\text { various concepts that have been studied. }\end{array}$ & 11,12 \\
\hline
\end{tabular}


The EKS instrument was made for the secondary school level. The indicators developed for EKS focused more on an environmental pollution problem. It was used to measure students' knowledge in dealing with various pollution problems that occur in their neighborhoods. The EKS instrument showed in Table 7.

\section{Table 7}

Indicators of the EKS instrument

\begin{tabular}{llc}
\hline \multicolumn{1}{c}{ Thinking Level } & \multicolumn{1}{c}{ Indicators } & Item \\
\hline Identify (TL-1) & Identifying the type of environmental pollution. & 1,2 \\
Compare (TL-2) & Comparing the factors causing pollution. & 3,4 \\
Implement (TL-3) & Implementing the concept of pollution reduction. & 5,6 \\
Criticize problem (TL-4) & Criticizing air pollution problems. & 7,8 \\
Solve Problem (TL-5) & Solving the environmental pollution problems. & 9,10 \\
Develop Innovation (TL-6) & Developing innovations to reduce pollution. & 11,12 \\
\hline
\end{tabular}

The NSKS instrument was made to measure students' knowledge of various natural science concepts. The NSKS instrument was made by adapting various contextual natural phenomena to be discussed. It was intended so that students can use various concepts of natural science to solve problems in everyday life. Details of the NSKS instrument can be seen in Table 8 .

\section{Table 8}

Indicators of the NSKS instrument

\begin{tabular}{|c|c|c|}
\hline Thinking Level & Indicators & Item \\
\hline Identify (TL-1) & Identifying various human organs. & 1,2 \\
\hline Compare (TL-2) & Comparing fish and poultry organs. & 3,4 \\
\hline Implement (TL-3) & $\begin{array}{l}\text { Implementing the concept of a healthy lifestyle for } \\
\text { organ health. }\end{array}$ & 5,6 \\
\hline Criticize problem (TL-4) & Criticizing students who do not want to exercise. & 7,8 \\
\hline Solve Problem (TL-5) & $\begin{array}{l}\text { Solving problems using the concepts of physics, chemis- } \\
\text { try, and biology. }\end{array}$ & 9,10 \\
\hline Develop Innovation (TL-6) & $\begin{array}{l}\text { Developing simple program ideas based on natural } \\
\text { science principles. }\end{array}$ & 11,12 \\
\hline
\end{tabular}

Meanwhile, the SSKS instrument was developed to measure students' knowledge in social sciences. The instrument consisted of 12 items covering a variety of general knowledge in the fields of geography, sociology, and economics. Detail of the SSKS instrument can be seen in Table 9 . 
Table 9

Indicators of the SSKS instrument

\begin{tabular}{|c|c|c|}
\hline Thinking Level & Indicators & Item \\
\hline Identify (TL-1) & $\begin{array}{l}\text { Identifying the names of cities and counties based on } \\
\text { geographic location. }\end{array}$ & 1,2 \\
\hline Compare (TL-2) & Comparing the differences between cities and counties. & 3,4 \\
\hline Implement (TL-3) & Implementing various social rules in the neighborhood. & 5,6 \\
\hline Criticize problem (TL-4) & $\begin{array}{l}\text { Criticizing problems of increase in foodstuffs during } \\
\text { holidays. }\end{array}$ & 7,8 \\
\hline Solve Problem (TL-5) & $\begin{array}{l}\text { Solving problems about students who don't want to } \\
\text { socialize. }\end{array}$ & 9,10 \\
\hline Develop Innovation (TL-6) & $\begin{array}{l}\text { Developing innovations to be able to socialize among } \\
\text { students outside the region. }\end{array}$ & 11,12 \\
\hline
\end{tabular}

\section{Validity and Reliability}

The validity test was carried out using SPSS with the Pearson Product Moment Correlation technique. The results showed that the instruments were categorized as valid for all items. The results of the validity test can be seen in Table 10.

Table 10

Instrument Validity Test Results

\begin{tabular}{|c|c|c|c|c|c|c|}
\hline Item No & EKU & NSKU & SSKU & EKS & NSKS & SSKS \\
\hline Item 1 & $.319^{* *}$ & $.572^{\star *}$ & $.630^{* *}$ & $.671^{\star *}$ & $.548^{\star \star}$ & $.466^{* *}$ \\
\hline Item 2 & $.599^{* *}$ & $.588^{\star *}$ & $.471^{\star *}$ & $.326^{\star *}$ & $.654^{\star *}$ & $.429^{\star *}$ \\
\hline Item 3 & $.502^{\star *}$ & $.569^{\star *}$ & $.842^{\star *}$ & $.362^{\star *}$ & $.606^{\star *}$ & $.401^{\star \star}$ \\
\hline Item 4 & $.535^{\star *}$ & $.682^{* *}$ & $.709^{\star *}$ & $.501^{\star *}$ & $.484^{\star *}$ & $.524^{\star \star}$ \\
\hline Item 5 & $.314^{\star *}$ & $.624^{\star *}$ & $.720^{\star *}$ & $.630^{* *}$ & $.663^{* *}$ & $.452^{\star *}$ \\
\hline Item 6 & $.620^{* *}$ & $.607^{\star *}$ & $.689^{* *}$ & $.613^{\star *}$ & $.687^{\star *}$ & $.420^{\star *}$ \\
\hline Item 7 & $.638^{\star *}$ & $.651^{\star *}$ & $.696^{* *}$ & $.562^{\star *}$ & $.491^{\star *}$ & $.612^{\star *}$ \\
\hline Item 8 & $.617^{\star *}$ & $.711^{\star *}$ & $.797^{\star *}$ & $.689^{* *}$ & $.509^{\star *}$ & $.620^{\star *}$ \\
\hline Item 9 & $.509^{* *}$ & $.638^{* *}$ & $.736^{\star *}$ & $.663^{\star *}$ & $.549^{\star *}$ & $.574^{\star *}$ \\
\hline Item 10 & $.604^{* *}$ & $.601^{\star *}$ & $.679^{* *}$ & $.559^{* *}$ & $.587^{\star *}$ & $.636^{* *}$ \\
\hline Item 11 & $.458^{\star *}$ & $.497^{\star *}$ & $.721^{\star *}$ & $.548^{\star *}$ & $.380^{\star *}$ & $.655^{\star *}$ \\
\hline Item 12 & $.471^{\star *}$ & $.686^{* *}$ & $.660^{* *}$ & $.552^{\star *}$ & $.347^{\star *}$ & $.659^{* *}$ \\
\hline
\end{tabular}

Note: ${ }^{* *}$ Valid at significance level 0.01 
The reliability value of each instrument was EKU (0.58), NSKU (0.74), SSKU (0.87), EKS (0.74), NSKS (0.63), and SSKS (0.59). The reliability results of the instrument showed that all instruments can be used to measure student knowledge. The results of this reliability calculation also showed that the instrument can be used in subsequent studies.

\section{Results}

The results indicated that the EKU score was still in a very low category. It suggested that students' knowledge from TL-1 to TL- 6 must be improved. It was especially in TL-6 which is related to developing innovative programs to overcome flood problems. Many students had not been able to create innovative programs and tended to create commonly conducted standard programs. It can be considered as not innovative. Details of the results can be seen in Table 11 .

\section{Table 11}

EKU Scores for Each Item

\begin{tabular}{|c|c|c|c|c|}
\hline No & $\begin{array}{l}\text { Thinking } \\
\text { Level }\end{array}$ & $\begin{array}{l}\text { Cate- } \\
\text { gory }\end{array}$ & Item & $\begin{array}{c}\text { All students } \\
\text { score } \\
(\mathrm{n}=128)\end{array}$ \\
\hline 1 & $\begin{array}{l}\text { Identify } \\
\text { (TL-1) }\end{array}$ & LOTS & $\begin{array}{l}\text { State various types of disasters that occurred in your } \\
\text { residential areas. }\end{array}$ & 3.86 \\
\hline 2 & $\begin{array}{l}\text { Identify } \\
\text { (TL-1) }\end{array}$ & LOTS & $\begin{array}{l}\text { Identify the disasters according to the categories of } \\
\text { caused by humans and purely due to natural factors }\end{array}$ & 4.50 \\
\hline 3 & $\begin{array}{l}\text { Compare } \\
\text { (TL-2) }\end{array}$ & LOTS & $\begin{array}{l}\text { The presence of Coronavirus Diseases } 2019 \text { (COV- } \\
\text { ID-19) has increased the number of types of disasters. } \\
\text { The Indonesian government has officially designated } \\
\text { COVID-19 as a non-natural disaster. List at least } 2 \\
\text { differences between natural and non-natural disasters. }\end{array}$ & 4.85 \\
\hline 4 & $\begin{array}{l}\text { Compare } \\
\text { (TL-2) }\end{array}$ & LOTS & $\begin{array}{l}\text { Compare the differences between a flood disaster event } \\
\text { and a landslide event. }\end{array}$ & 4.35 \\
\hline 5 & $\begin{array}{l}\text { Implement } \\
\text { (TL-3) }\end{array}$ & LOTS & What efforts can be implemented to prevent flooding? & 3.39 \\
\hline 6 & $\begin{array}{l}\text { Implement } \\
\text { (TL-3) }\end{array}$ & LOTS & $\begin{array}{l}\text { Explain the application of technology to prevent dis- } \\
\text { asters in the environment. }\end{array}$ & 3.49 \\
\hline 7 & $\begin{array}{l}\text { Criticize } \\
\text { Problem } \\
\text { (TL-4) }\end{array}$ & HOTS & Give critique of the behavior of people who like to litter & 3.61 \\
\hline 8 & $\begin{array}{l}\text { Criticize } \\
\text { Problem } \\
\text { (TL-4) }\end{array}$ & HOTS & $\begin{array}{l}\text { What critique can be given to people who frequently } \\
\text { use plastic bags? }\end{array}$ & 3.15 \\
\hline
\end{tabular}




\begin{tabular}{|c|c|c|c|c|}
\hline No & $\begin{array}{c}\text { Thinking } \\
\text { Level }\end{array}$ & $\begin{array}{l}\text { Cate- } \\
\text { gory }\end{array}$ & Item & $\begin{array}{c}\text { All students } \\
\text { score } \\
(\mathrm{n}=128)\end{array}$ \\
\hline 9 & $\begin{array}{l}\text { Solve } \\
\text { Problem } \\
(\mathrm{TL}-5)\end{array}$ & HOTS & $\begin{array}{l}\text { Provide solutions to the problem of low water catch- } \\
\text { ment areas in urban areas. }\end{array}$ & 2.77 \\
\hline 10 & $\begin{array}{l}\text { Solve } \\
\text { Problem } \\
(\mathrm{TL}-5)\end{array}$ & HOTS & $\begin{array}{l}\text { In your opinion, what solutions can be done to reduce } \\
\text { the problem of mounting garbage? }\end{array}$ & 2.92 \\
\hline 11 & $\begin{array}{l}\text { Develop } \\
\text { Innovation } \\
(\mathrm{TL}-6)\end{array}$ & HOTS & $\begin{array}{l}\text { Develop an innovative program to solve flooding } \\
\text { problem that occurs in large urban areas. }\end{array}$ & 2.41 \\
\hline \multirow[t]{4}{*}{12} & $\begin{array}{l}\text { Develop } \\
\text { Innovation } \\
\text { (TL-6) }\end{array}$ & HOTS & $\begin{array}{l}\text { Write down at least one innovative idea to solve the air } \\
\text { pollution problem. }\end{array}$ & 2.52 \\
\hline & & & Raw score & 41.82 \\
\hline & & & Net score (0-100 interval) & 34.85 \\
\hline & & & Category & Very low \\
\hline
\end{tabular}

Regarding the NSKU score, it indicated that students in general had not been able to understand the concept of natural sciences as a whole. It was evidenced by a very low knowledge score. The lowest score obtained on TL- 6 that is related to innovation during the Coronavirus Diseases 2019 (COVID-19) pandemic to address the problem of scarce clean water supplies. It can be seen more clearly in Table 12 .

\section{Table 12}

NSKU Score for Each Item

\begin{tabular}{|c|c|c|c|c|}
\hline No & $\begin{array}{l}\text { Thinking } \\
\text { Level }\end{array}$ & $\begin{array}{l}\text { Cate- } \\
\text { gory }\end{array}$ & Item & $\begin{array}{c}\text { All students } \\
\text { score } \\
(\mathbf{n}=131)\end{array}$ \\
\hline 1 & $\begin{array}{l}\text { Identify } \\
\text { (TL-1) }\end{array}$ & LOTS & $\begin{array}{l}\text { Identify name physical and chemical factors that can } \\
\text { affect the survival of living things. }\end{array}$ & 4.19 \\
\hline 2 & $\begin{array}{l}\text { Identify } \\
\text { (TL-1) }\end{array}$ & LOTS & $\begin{array}{l}\text { Identify various types of living things that can live } \\
\text { in environments with hot temperatures and cold } \\
\text { temperatures. }\end{array}$ & 4.27 \\
\hline 3 & $\begin{array}{l}\text { Compare } \\
(\mathrm{TL}-2)\end{array}$ & LOTS & $\begin{array}{l}\text { Explain the differences between air temperature and } \\
\text { water } \mathrm{pH} \text { factors for human survival. }\end{array}$ & 3.97 \\
\hline 4 & $\begin{array}{l}\text { Compare } \\
(\mathrm{TL}-2)\end{array}$ & LOTS & $\begin{array}{l}\text { Compare the roles of } \mathrm{H} 2 \mathrm{SO} 4 \text { (sulfuric acid) and } \\
\mathrm{HCl} \text { (hydrochloric acid) for nature and living things. }\end{array}$ & 3.88 \\
\hline 5 & $\begin{array}{l}\text { Implement } \\
(\mathrm{TL}-3)\end{array}$ & LOTS & $\begin{array}{l}\text { How is the concept of gravity applied to reduce the } \\
\text { burden of hiking? Give explanation. }\end{array}$ & 3.27 \\
\hline
\end{tabular}




\begin{tabular}{|c|c|c|c|c|}
\hline No & $\begin{array}{l}\text { Thinking } \\
\text { Level }\end{array}$ & $\begin{array}{l}\text { Cate- } \\
\text { gory }\end{array}$ & Item & $\begin{array}{l}\text { All students } \\
\text { score } \\
(\mathbf{n}=131)\end{array}$ \\
\hline 6 & $\begin{array}{l}\text { Implement } \\
(\mathrm{TL}-3)\end{array}$ & LOTS & $\begin{array}{l}\text { Explain the application of formaldehyde substances } \\
\text { according to their correct function. }\end{array}$ & 3.63 \\
\hline 7 & $\begin{array}{l}\text { Criticize } \\
\text { Problem } \\
(\mathrm{TL}-4)\end{array}$ & HOTS & $\begin{array}{l}\text { Give critique for the problem of the high price of } \\
\text { electric cars. }\end{array}$ & 3.50 \\
\hline 8 & $\begin{array}{l}\text { Criticize } \\
\text { Problem } \\
(\mathrm{TL}-4)\end{array}$ & HOTS & $\begin{array}{l}\text { Describe alternative natural ingredients for making } \\
\text { hand sanitizers. Write constructive critique for the } \\
\text { hand sanitizer scarcity problem. }\end{array}$ & 3.85 \\
\hline 9 & $\begin{array}{l}\text { Solve Prob- } \\
\text { lem (TL-5) }\end{array}$ & HOTS & $\begin{array}{l}\text { Provide solutions to the perishable fruit rottenness } \\
\text { problem from physical, chemical, and biological } \\
\text { approaches. }\end{array}$ & 3.18 \\
\hline 10 & $\begin{array}{l}\text { Solve Prob- } \\
\text { lem (TL-5) }\end{array}$ & HOTS & $\begin{array}{l}\text { Provide solutions to the problem of low public } \\
\text { awareness in checking body temperature using a } \\
\text { Thermogun. }\end{array}$ & 3.08 \\
\hline 11 & $\begin{array}{l}\text { Develop } \\
\text { Innovation } \\
\text { (TL-6) }\end{array}$ & HOTS & $\begin{array}{l}\text { What innovations can be developed to overcome the } \\
\text { problem of lack of clean water supplies during the } \\
\text { COVID-19 pandemic? }\end{array}$ & 2.27 \\
\hline \multirow[t]{4}{*}{12} & $\begin{array}{l}\text { Develop } \\
\text { Innovation } \\
\text { (TL-6) }\end{array}$ & HOTS & $\begin{array}{l}\text { As a student, what innovations can you develop } \\
\text { to make medicines from natural ingredients and } \\
\text { explain their uses? }\end{array}$ & 2.79 \\
\hline & & & Raw score & 41.88 \\
\hline & & & Net score (0-100 interval) & 34.90 \\
\hline & & & Category & Very low \\
\hline
\end{tabular}

Students' knowledge in terms of social science obtained the lowest score at TL-6. This showed that students had not been able to contribute in the form of innovation to solve the problem of lack of employment in the surrounding community. Students who study various social sciences should have ideas and innovations to solve this problem. The SSKU scores can be seen in Table 13. 
Table 13

SSKU Scores for Each Item

\begin{tabular}{|c|c|c|c|c|}
\hline No & $\begin{array}{l}\text { Thinking } \\
\text { Level }\end{array}$ & $\begin{array}{l}\text { Cate- } \\
\text { gory }\end{array}$ & Item & $\begin{array}{l}\text { All students } \\
\text { score } \\
(\mathbf{n}=75)\end{array}$ \\
\hline 1 & $\begin{array}{l}\text { Identify } \\
(\mathrm{TL}-1)\end{array}$ & LOTS & $\begin{array}{l}\text { Identify the causes of the increase in food prices } \\
\text { ahead of the holidays from an economic and social } \\
\text { perspective. }\end{array}$ & 5.95 \\
\hline 2 & $\begin{array}{l}\text { Identify } \\
\text { (TL-1) }\end{array}$ & LOTS & $\begin{array}{l}\text { Identify various natural resources around your envi- } \\
\text { ronment that have economic values. }\end{array}$ & 4.64 \\
\hline 3 & $\begin{array}{l}\text { Compare } \\
(\mathrm{TL}-2)\end{array}$ & LOTS & $\begin{array}{l}\text { Explain the differences between the panic buying } \\
\text { phenomenon and normal situation for the community } \\
\text { in terms of the social, economic, and geographical } \\
\text { location of residence. }\end{array}$ & 5.20 \\
\hline 4 & $\begin{array}{l}\text { Compare } \\
(\mathrm{TL}-2)\end{array}$ & LOTS & $\begin{array}{l}\text { The terms of physical distancing and social distancing } \\
\text { have been discussed some time ago. In your opinion, } \\
\text { what are the differences between the two terms from } \\
\text { a social and economic perspective? }\end{array}$ & 4.16 \\
\hline 5 & $\begin{array}{l}\text { Implement } \\
\text { (TL-3) }\end{array}$ & LOTS & $\begin{array}{l}\text { What types of work can and cannot be implemented } \\
\text { using the work from home concept during COVID-19? }\end{array}$ & 3.79 \\
\hline 6 & $\begin{array}{l}\text { Implement } \\
\text { (TL-3) }\end{array}$ & LOTS & $\begin{array}{l}\text { The existence of COVID-19 has caused various } \\
\text { kinds of financial difficulties in various sectors. What } \\
\text { concepts should the community implement so that } \\
\text { finances and economies are not disturbed? }\end{array}$ & 3.05 \\
\hline 7 & $\begin{array}{l}\text { Criticize } \\
\text { Problem } \\
\text { (TL-4) }\end{array}$ & HOTS & $\begin{array}{l}\text { Geographically, some of the Indonesian border areas } \\
\text { are located in the outermost and remote island areas. } \\
\text { The monitoring of the border areas has sometimes } \\
\text { become an opening for foreigners to enter without } \\
\text { permission. Give critique to this problem. }\end{array}$ & 3.11 \\
\hline 8 & $\begin{array}{l}\text { Criticize } \\
\text { Problem } \\
(\mathrm{TL}-4)\end{array}$ & HOTS & $\begin{array}{l}\text { Give critique for the lack of supplies of evacuation } \\
\text { places when a disaster occurs. }\end{array}$ & 3.08 \\
\hline 9 & $\begin{array}{l}\text { Solve } \\
\text { Problem } \\
(\mathrm{TL}-5)\end{array}$ & HOTS & $\begin{array}{l}\text { In your opinion, what solutions can be done to solve } \\
\text { the lack of employment problem }\end{array}$ & 3.09 \\
\hline 10 & $\begin{array}{l}\text { Solve } \\
\text { Problem } \\
\text { (TL-5) }\end{array}$ & HOTS & $\begin{array}{l}\text { What solutions can you offer to overcome the eco- } \\
\text { nomic downturn during a pandemic? }\end{array}$ & 2.77 \\
\hline 11 & $\begin{array}{l}\text { Develop } \\
\text { Innovation } \\
\text { (TL-6) }\end{array}$ & HOTS & $\begin{array}{l}\text { Develop smartphone-based ideas and innovations to } \\
\text { solve unemployment problem in the society. }\end{array}$ & 2.32 \\
\hline \multirow[t]{4}{*}{12} & $\begin{array}{l}\text { Develop } \\
\text { Innovation } \\
\text { (TL-6) }\end{array}$ & HOTS & $\begin{array}{l}\text { Develop various innovations that can be done to invite } \\
\text { people to be willing to share with those in need. }\end{array}$ & 2.67 \\
\hline & & & Raw score & 43.83 \\
\hline & & & Net score (0-100 interval) & 36.52 \\
\hline & & & Category & Very low \\
\hline
\end{tabular}


The results of the EKS measurement implied that the overall student score was still in a very low category for understanding various environmental concepts. The lowest score on EKS was found on items with TL-6 that is related to innovation for environmentally friendly campaign in the wider community. The results can be seen in Table 14.

Table 14

EKS Score for Each Item

\begin{tabular}{|c|c|c|c|c|c|}
\hline No & $\begin{array}{l}\text { Thinking } \\
\text { Level }\end{array}$ & Category & Item & $\begin{array}{l}\text { JHS } \\
\text { students } \\
\text { score } \\
(\mathbf{n}=68)\end{array}$ & $\begin{array}{l}\text { SHS } \\
\text { students } \\
\text { score } \\
(\mathbf{n}=119)\end{array}$ \\
\hline 1 & $\begin{array}{l}\text { Identify } \\
\text { (TL-1) }\end{array}$ & LOTS & $\begin{array}{l}\text { Identify different types of pollution in the } \\
\text { environment. }\end{array}$ & 3.76 & 4.82 \\
\hline 2 & $\begin{array}{l}\text { Identify } \\
(\mathrm{TL}-1)\end{array}$ & LOTS & $\begin{array}{l}\text { What type of pollution occurs most } \\
\text { frequently in the area where you live? } \\
\text { Mention. }\end{array}$ & 3.07 & 3.46 \\
\hline 3 & $\begin{array}{l}\text { Compare } \\
\text { (TL-2) }\end{array}$ & LOTS & $\begin{array}{l}\text { Describe } 2 \text { differences in pollution caused } \\
\text { by natural and human events. }\end{array}$ & 4.18 & 4.31 \\
\hline 4 & $\begin{array}{l}\text { Compare } \\
(\mathrm{TL}-2)\end{array}$ & LOTS & $\begin{array}{l}\text { Does pollution from forest fires include } \\
\text { pollution from nature or humans? Give } \\
\text { explanation. }\end{array}$ & 3.41 & 3.83 \\
\hline 5 & $\begin{array}{l}\text { Implement } \\
(\mathrm{TL}-3)\end{array}$ & LOTS & $\begin{array}{l}\text { How is the concept of "going green" ap- } \\
\text { plied to your daily life? Give explanation. }\end{array}$ & 3.47 & 4.06 \\
\hline 6 & $\begin{array}{l}\text { Implement } \\
(\mathrm{TL}-3)\end{array}$ & LOTS & $\begin{array}{l}\text { What efforts can you do to reduce pol- } \\
\text { lution around your home environment? }\end{array}$ & 3.22 & 3.61 \\
\hline 7 & $\begin{array}{l}\text { Criticize } \\
\text { Problem } \\
\text { (TL-4) }\end{array}$ & HOTS & $\begin{array}{l}\text { Give critique to people who keep burning } \\
\text { trash and polluting the air. }\end{array}$ & 2.71 & 3.08 \\
\hline 8 & $\begin{array}{l}\text { Criticize } \\
\text { Problem } \\
(\mathrm{TL}-4)\end{array}$ & HOTS & $\begin{array}{l}\text { What critique can be given to individual } \\
\text { textile factory employees who dump waste } \\
\text { in the river? }\end{array}$ & 2.51 & 3.06 \\
\hline 9 & $\begin{array}{l}\text { Solve Prob- } \\
\text { lem (TL-5) }\end{array}$ & HOTS & $\begin{array}{l}\text { What solutions can you offer to solve } \\
\text { air pollution problem that occurs in big } \\
\text { cities? }\end{array}$ & 2.51 & 3.00 \\
\hline 10 & $\begin{array}{l}\text { Solve Prob- } \\
\text { lem (TL-5) }\end{array}$ & HOTS & $\begin{array}{l}\text { Provide a solution to the community for } \\
\text { not throwing garbage in the river. }\end{array}$ & 2.81 & 3.16 \\
\hline 11 & $\begin{array}{l}\text { Develop } \\
\text { Innovation } \\
\text { (TL-6) }\end{array}$ & HOTS & $\begin{array}{l}\text { Write brilliant ideas to invite classmates } \\
\text { to protect the environment. }\end{array}$ & 2.41 & 2.71 \\
\hline \multirow[t]{4}{*}{12} & $\begin{array}{l}\text { Develop } \\
\text { Innovation } \\
\text { (TL-6) }\end{array}$ & HOTS & $\begin{array}{l}\text { Write a simple idea that can be used for a } \\
\text { campaign about environmentally friendly } \\
\text { attitude to the wider community. }\end{array}$ & 2.19 & 2.56 \\
\hline & & & Raw score & 36.25 & 41.66 \\
\hline & & & Net score (0-100 interval) & 30.21 & 34.72 \\
\hline & & & Category & Very low & Very low \\
\hline
\end{tabular}


The NSKS scores obtained by JHS and SHS students were also in a very low category. It could be assumed that natural science learning in schools has not run optimally. The lowest score from the NSKS was found in item 12 regarding making innovative ideas to invite the public to maintain cleanliness. The detail of NSKS scores can be seen in Table 15.

\section{Table 15}

NSKS Score for Each Item

\begin{tabular}{|c|c|c|c|c|c|}
\hline No & $\begin{array}{l}\text { Thinking } \\
\text { Level }\end{array}$ & $\begin{array}{l}\text { Cate- } \\
\text { gory }\end{array}$ & Item & $\begin{array}{l}\text { JHS stu- } \\
\text { dents score } \\
(\mathbf{n}=77)\end{array}$ & $\begin{array}{l}\text { SHS stu- } \\
\text { dents score } \\
(\mathrm{n}=198)\end{array}$ \\
\hline 1 & $\begin{array}{l}\text { Identify } \\
(\mathrm{TL}-1)\end{array}$ & LOTS & $\begin{array}{l}\text { Identify name of human organs that play } \\
\text { a role in the digestive system. }\end{array}$ & 3.87 & 4.94 \\
\hline 2 & $\begin{array}{l}\text { Identify } \\
(\mathrm{TL}-1)\end{array}$ & LOTS & $\begin{array}{l}\text { Identify human organs that work for the } \\
\text { respiratory process. }\end{array}$ & 3.64 & 4.81 \\
\hline 3 & $\begin{array}{l}\text { Compare } \\
\text { (TL-2) }\end{array}$ & LOTS & $\begin{array}{l}\text { Explain } 2 \text { differences in respiratory appa- } \\
\text { ratus of birds and goldfish. }\end{array}$ & 3.88 & 4.45 \\
\hline 4 & $\begin{array}{l}\text { Compare } \\
\text { (TL-2) }\end{array}$ & LOTS & $\begin{array}{l}\text { Explain } 2 \text { differences in locomotion of } \\
\text { birds and catfish. }\end{array}$ & 3.90 & 4.24 \\
\hline 5 & $\begin{array}{l}\text { Implement } \\
(\mathrm{TL}-3)\end{array}$ & LOTS & $\begin{array}{l}\text { What kind of healthy lifestyle can be } \\
\text { applied to maintain the health of the res- } \\
\text { piratory organs? Give explanation. }\end{array}$ & 3.45 & 3.78 \\
\hline 6 & $\begin{array}{l}\text { Implement } \\
(\mathrm{TL}-3)\end{array}$ & LOTS & $\begin{array}{l}\text { Describe efforts that can be made to main- } \\
\text { tain heart health. }\end{array}$ & 2.99 & 3.69 \\
\hline 7 & $\begin{array}{l}\text { Criticize } \\
\text { Problem } \\
(\mathrm{TL}-4)\end{array}$ & HOTS & $\begin{array}{l}\text { Give critique to your friends who are } \\
\text { lazy to exercise because they don't have } \\
\text { expensive / branded sports shoes. }\end{array}$ & 3.09 & 3.35 \\
\hline 8 & $\begin{array}{l}\text { Criticize } \\
\text { Problem } \\
(\mathrm{TL}-4)\end{array}$ & HOTS & $\begin{array}{l}\text { Give suggestions and critique so that your } \\
\text { classmates diligently exercise every day. }\end{array}$ & 2.62 & 3.23 \\
\hline 9 & $\begin{array}{l}\text { Solve Prob- } \\
\text { lem (TL-5) }\end{array}$ & HOTS & $\begin{array}{l}\text { Wooden cabinets are often fragile by ter- } \\
\text { mites. Provide a solution to this problem } \\
\text { using studied natural science concepts. }\end{array}$ & 2.70 & 2.91 \\
\hline 10 & $\begin{array}{l}\text { Solve Prob- } \\
\text { lem (TL-5) }\end{array}$ & HOTS & $\begin{array}{l}\text { How do you preserve food without pre- } \\
\text { servatives? Provide solutions to solve this } \\
\text { problem according to the concepts of } \\
\text { physics, chemistry, and biology. }\end{array}$ & 2.94 & 3.24 \\
\hline 11 & $\begin{array}{l}\text { Develop } \\
\text { Innovation } \\
(\mathrm{TL}-6)\end{array}$ & HOTS & $\begin{array}{l}\text { Write down ideas that you can give to } \\
\text { invite people to wear masks during the } \\
\text { COVID-19 pandemic. }\end{array}$ & 2.34 & 2.56 \\
\hline \multirow[t]{4}{*}{12} & $\begin{array}{l}\text { Develop } \\
\text { Innovation } \\
(\mathrm{TL}-6)\end{array}$ & HOTS & $\begin{array}{l}\text { What innovative ideas can be done to } \\
\text { overcome the problem of low public } \\
\text { awareness to maintain cleanliness during } \\
\text { COVID-19. }\end{array}$ & 2.13 & 2.55 \\
\hline & & & Raw score & 37.55 & 43.75 \\
\hline & & & Net score (0-100 interval) & 31.29 & 36.46 \\
\hline & & & Category & Very low & Very low \\
\hline
\end{tabular}


The SSKS instrument is made with a wide range of social knowledge. The goal is that students can think to solve social problems from various aspects of science. The lowest score from SSKS was on items related to implementation (TL-3) as regards the application of social sanctions. In addition, a low score also was obtained by developing innovation (TL-6) that is related to developing innovative ideas so that students between regions can interact online. The details of the SSKS score can be seen in Table 16.

\section{Table 16}

SSKS score for Each Item

\begin{tabular}{|c|c|c|c|c|c|}
\hline No & $\begin{array}{c}\text { Thinking } \\
\text { Level }\end{array}$ & $\begin{array}{l}\text { Cate- } \\
\text { gory }\end{array}$ & Item & $\begin{array}{c}\text { JHS } \\
\text { students } \\
\text { score } \\
(\mathrm{n}=66) \\
\end{array}$ & $\begin{array}{c}\text { SHS } \\
\text { students } \\
\text { score } \\
(\mathrm{n}=168) \\
\end{array}$ \\
\hline 1 & $\begin{array}{l}\text { Identify } \\
\text { (TL-1) }\end{array}$ & LOTS & Identify the name of 3 districts in West Java. & 5.58 & 5.79 \\
\hline 2 & $\begin{array}{l}\text { Identify } \\
\text { (TL-1) }\end{array}$ & LOTS & $\begin{array}{l}\text { What districts are there in Central Java? } \\
\text { Please identify. }\end{array}$ & 5.89 & 5.73 \\
\hline 3 & $\begin{array}{l}\text { Compare } \\
(\mathrm{TL}-2)\end{array}$ & LOTS & $\begin{array}{l}\text { What are the differences between a district } \\
\text { and a municipality? Describe } 2 \text { aspects that } \\
\text { differentiate it. }\end{array}$ & 3.94 & 4.61 \\
\hline 4 & $\begin{array}{l}\text { Compare } \\
\text { (TL-2) }\end{array}$ & LOTS & $\begin{array}{l}\text { Describe } 2 \text { differences between regents } \\
\text { and mayors according to their functions } \\
\text { and duties. }\end{array}$ & 4.45 & 4.22 \\
\hline 5 & $\begin{array}{l}\text { Implement } \\
\text { (TL-3) }\end{array}$ & LOTS & $\begin{array}{l}\text { What social sanctions can be applied to } \\
\text { people who use the sidewalk to trade? Give } \\
\text { explanation. }\end{array}$ & 2.32 & 2.85 \\
\hline 6 & $\begin{array}{l}\text { Implement } \\
\text { (TL-3) }\end{array}$ & LOTS & $\begin{array}{l}\text { There are often people who smoke in the } \\
\text { no-smoking area. What efforts can be im- } \\
\text { plemented to prevent people from smoking } \\
\text { in the no-smoking area? }\end{array}$ & 2.62 & 2.68 \\
\hline 7 & $\begin{array}{l}\text { Criticize } \\
\text { Problem } \\
(\mathrm{TL}-4)\end{array}$ & HOTS & $\begin{array}{l}\text { Give critique to people who like to hoard } \\
\text { foodstuffs before holidays so that supplies } \\
\text { become scarce. }\end{array}$ & 3.02 & 3.23 \\
\hline 8 & $\begin{array}{l}\text { Criticize } \\
\text { Problem } \\
(\mathrm{TL}-4)\end{array}$ & HOTS & $\begin{array}{l}\text { Give critique on the behavior of consumers } \\
\text { who like to buy an item without considera- } \\
\text { tion so that it creates scarcity and prices rise. }\end{array}$ & 2.86 & 2.98 \\
\hline 9 & $\begin{array}{l}\text { Solve Prob- } \\
\text { lem (TL-5) }\end{array}$ & HOTS & $\begin{array}{l}\text { Provide a solution for a friend who is hard } \\
\text { to get along with and doesn't want to inter- } \\
\text { act during the lesson. }\end{array}$ & 2.65 & 2.88 \\
\hline 10 & $\begin{array}{l}\text { Solve Prob- } \\
\text { lem (TL-5) }\end{array}$ & HOTS & $\begin{array}{l}\text { What solutions can be given to friends who } \\
\text { cannot discuss in group learning activities, } \\
\text { provide solutions according to the social } \\
\text { science concepts that have been studied. }\end{array}$ & 2.55 & 2.85 \\
\hline 11 & $\begin{array}{l}\text { Develop } \\
\text { Innovation } \\
\text { (TL-6) }\end{array}$ & HOTS & $\begin{array}{l}\text { Give ideas or thoughts so that students from } \\
\text { various regions could interact online amid } \\
\text { the COVID } 19 \text { pandemic. }\end{array}$ & 2.41 & 2.39 \\
\hline
\end{tabular}




\begin{tabular}{cccccc}
\hline No & $\begin{array}{c}\text { Thinking } \\
\text { Level }\end{array}$ & $\begin{array}{c}\text { Cate- } \\
\text { gory }\end{array}$ & \multicolumn{1}{c}{ Item } & $\begin{array}{c}\text { JHS } \\
\text { students } \\
\text { score } \\
(\mathbf{n = 6 6 )}\end{array}$ & $\begin{array}{c}\text { SHS } \\
\text { students } \\
\text { score } \\
(\mathbf{n}=\mathbf{1 6 8})\end{array}$ \\
\hline 12 & $\begin{array}{l}\text { Develop } \\
\text { Innovation } \\
\text { (TL-6) }\end{array}$ & HOTS & $\begin{array}{l}\text { Give bright ideas to support government } \\
\text { programs in home learning activities. What } \\
\text { breakthroughs should be made to keep }\end{array}$ & 2.41 & 2.99 \\
& & $\begin{array}{l}\text { learning activities fun? } \\
\text { Raw score }\end{array}$ & 40.70 & 43.20 \\
& Net score (0-100 interval) & 33.92 & 36.00 \\
\hline & Category & Very low & Very low \\
\hline
\end{tabular}

The study results as a whole stated that the knowledge of the college students and students was still in the very low category. Therefore, efforts to develop various innovations in education must be increased. The innovation should be aimed at improving the LOTS and HOTS domains. Figure 2 describes the learning process to improve knowledge.

Figure 2

Learning Process to Improve LOTS and HOTS

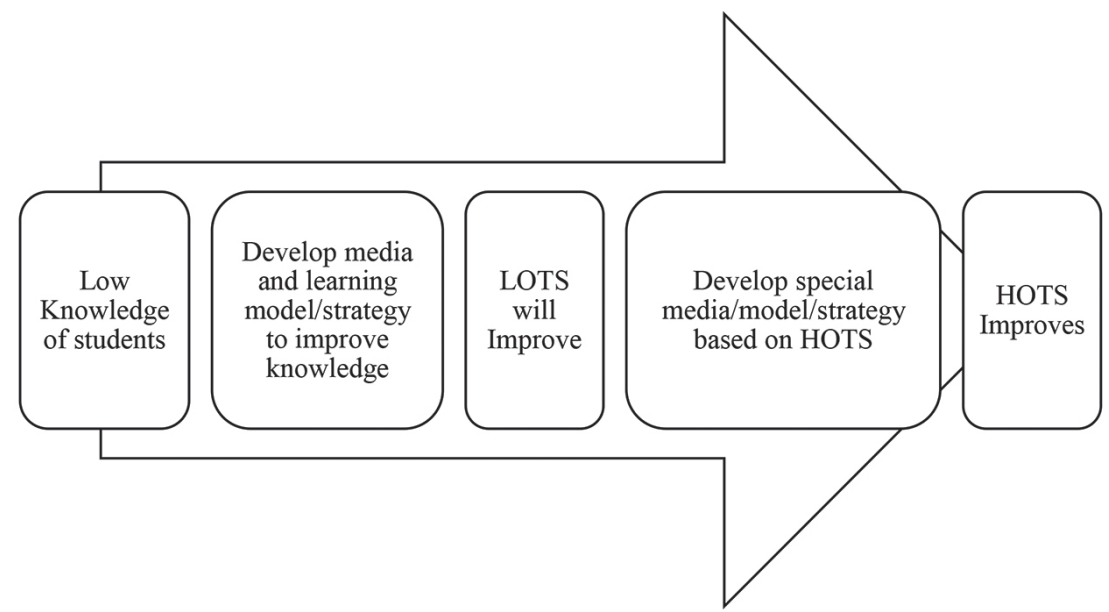

\section{Discussion}

Students' abilities in the LOTS need to be improved. This is because LOTS is a basic ability for someone to understand more complicated matters. LOTS is important because it is an initial ability to improve HOTS (Fitzpatrick \& Schulz, 2015; Istiyono et al., 2020; Yeung, 2015). Students who have sufficient LOTS will be able to identify various things around them. Learning at various levels must make the LOTS stronger so that students 
find it easier to practice HOTS skills. Both abilities must be enhanced by carrying out various innovations in technology-based education to accommodate various abilities of the 21st century (Boholano, 2017; Cukurova \& Bennett, 2018; Ichsan et al., 2020; Quieng et al., 2015; Sigit et al., 2020; Urbani et al., 2017).

The LOTS ability in Anderson's Taxonomy consists of 3 skills, namely: remember, understand, and apply. The ability was less accurate to measure students' abilities in the 21st century. In this century, students no longer remember the learning topics, but they must also be able to identify various things around them. The ability to identify is much more important and contextual than just remembering. Additionally, the ability to understand turns into the ability to compare. It is easier to measure students' ability to "compare" than to "understand" as understanding is a very broad yet less operational aspect. The final LOTS level is the ability to apply that has changed into implementing various concepts. The change in thinking skills in the LOTS was following the needs of students who can be contextual in understanding various contextual topics (Cronje et al., 2011; Mendhurwar \& Mishra, 2018; Paristiowati et al., 2019; Sahronih et al., 2019).

Once students have mastered the LOTS abilities, their HOTS abilities begin to be trained at the same time. This was important because HOTS ability is the ability to solve a problem and develop innovation to solve the problem (Elfeky, 2018; Husamah et al., 2018; Tanujaya et al., 2017; Vidergor, 2018). The HOTS domains of Anderson's Taxonomy consist of: analyze, evaluate, and create. The domains had changed into criticize problems, solve problems, and develop innovation. The changes were adapted from the HOTSEP taxonomy in previous studies (Ichsan \& Rahmayanti, 2020). The difference was that changes in the HOTS domain in the new taxonomy were more general for all subject topics instead of merely the environment topic. The change in the HOTS was important because students in the 21st century must be more critical in responding to various problems that occur (Anagun, 2018; Lee, 2016; Smith, 2014; Suwono et al., 2017).

The change from Analyze (TL-4) to Solve Problem (TL-5) that increased the level from level 4 to 5 was due to the need to not merely analyze a problem. Students in the 21 st century also require problem-solving skills. In addition, students' ability to analyze will be easier to measure in the solve problem aspect. It has to do with students' ability to analyze that was hard to show in a concrete or contextual form. The score given for the ability to analyze was also difficult because it was more subjective to assess a person's ability to analyze. The second change was in evaluate (TL-5) to criticize problem (TL-4) which has a decreased level. This was because it is hard to measure students' ability to evaluate. Students must be able to criticize a problem. The ability to criticize a problem will be easier to measure than the ability to evaluate something. The last change was in Create (TL-6) that became develop innovation (TL-6). The level remained at the highest level. The change occurred because students in the 21st century are not only required to create something but develop an innovation. Students not only create standard work but must 
be accompanied by innovative ideas. These innovative ideas are very important to form creativity and originality in a work (Cheng et al., 2016; Lince, 2016; Ritter \& Mostert, 2017).

Education must be strengthened in studying various topics of environment, natural sciences, and social and other sciences. This research showed that it is necessary to perform various educational innovations in terms of learning. The low knowledge score indicates that learning media, learning strategies, learning models, student worksheets and various learning tools need to be developed. Innovations must be made especially to improve students' HOTS in learning on various topics. The topics of environment, natural sciences, and social sciences are the most common topics and must be mastered by all students. Knowledge of the environment will make students better understand and grasp the various problems of environmental damage (Arnon et al., 2015; Goldman et al., 2017; Kinslow et al., 2018). Likewise, various concepts of natural sciences and social sciences need to be mastered to fit the 21st-century educational context (Calado et al., 2018; Dani, 2011; Sarkar \& Corrigan, 2014). This new taxonomy can also be implemented in various subjects such as citizenship, language, engineering, mathematics, sports, arts, and other subjects at the school to university level.

\section{Conclusion}

Based on the results, a new taxonomy has been developed and a conclusion could be drawn that student's knowledge scores are all still in the very low category. The new taxonomy measures student knowledge more accurate and contextual according to the needs of the 21st century. Students in the 21st century are expected not only to create something but also products or ideas that are developed to be original and innovative. It indicated the need for innovation in education. Besides, efforts are also needed to develop various learning tools, learning models, learning strategies, learning media, teaching materials, and other equipment.

\section{Suggestions and Limitation}

The limitation of this study includes the sample used that was limited to measure environmental knowledge, natural sciences knowledge, and social sciences knowledge. Meanwhile, measurements for other subjects have not been carried out using the new taxonomy. The suggestion of this study is to measure knowledge of other subjects/learning topics using a new taxonomy. Moreover, it is necessary to develop various educational innovations to strengthen student knowledge in various subjects and at various levels. 


\section{References}

Anagun, S. S. (2018). Teachers' perceptions about the relationship between 21st century skills and managing constructivist learning environments. International Journal of Instruction, 11(4), 825-840. https://doi.org/10.12973/iji.2018.11452a

Anderson, L. W., Krathwohl, D. R., Airiasian, W., Cruikshank, K. A., Mayer, R. E., Pintrich, P. R., Raths, J., \& Wittrock, M. C. (2001). A taxonomy for learning, teaching and assessing: A revision of bloom's taxonomy of educational objectives. London: Longman.

Arnon, S., Orion, N., \& Carmi, N. (2015). Environmental literacy components and their promotion by institutions of higher education: an Israeli case study. Environmental Education Research, 21(7), 1029-1055. https://doi.org/10.1080/13504622.2014.966656

Beckwith, P. T. (2019). The HOTSHOT taxonomy and a signature pedagogy framework for operating department practice: The juxtaposition to the academic apartheid surrounding higher order thinking. Journal of Perioperative Practice, 29(6), 185-192. https://doi. $\operatorname{org} / 10.1177 / 1750458918820729$

Bigirwa, J. P., Ndawula, S., \& Naluwemba, E. F. (2020). On-line quality management a precursor for improving e-learning adoption in midwifery schools in Uganda. International Journal of Educational Methodology, 6(2), 271-283. https://doi.org/10.12973/ijem.6.2.271

Bilasa, P., \& Taspinar, M. (2020). Opinions of the students from foreign language teaching departments about their undergraduate programs. International Journal of Educational Methodology, 6(2), 367-380. https://doi.org/10.12973/ijem.6.2.367

Bodzin, A., Hammond, T., Fu, Q., \& Farina, W. (2020). Development of instruments to assess students' spatial learning attitudes (SLA) and interest in science, technology and geospatial technology (STEM-GEO). International Journal of Educational Methodology, 6(1), 67-81. https://doi.org/10.12973/ijem.6.1.67

Boholano, H. B. (2017). Smart social networking: 21st century teaching and learning skills. Research in Pedagogy, 7(1), 21-29. https://doi.org/10.17810/2015.45

Calado, F. M., Scharfenberg, F. J., \& Bogner, F. X. (2018). Science-technology-society-environment issues in German and Portuguese biology textbooks: influenced of the socio-cultural context? International Journal of Science Education, Part B: Communication and Public Engagement, 8(3), 266-286. https://doi.org/10.1080/21548455.2018.1486051

Cheng, Y. Y., Chien, C. C., \& Wang, S. J. (2016). The Effect of the Accounting and Business Curriculums on Creativity. Journal of Curriculum and Teaching, 5(2), 127-143. https://doi. org/10.5430/jct.v5n2p127

Cronje, R., Rohlinger, S., Crall, A., \& Newman, G. (2011). Does participation in citizen science improve scientific literacy? A study to compare assessment methods. Applied Environmental Education and Communication, 10(3), 135-145. https://doi.org/10.1080/1533015X.2011.603611

Cukurova, M., \& Bennett, J. (2018). Students' knowledge acquisition and ability to apply knowledge into different science contexts in two different independent learning settings. Research in Science and Technological Education, 36(1), 17-34. https://doi.org/10.1080/02635143.2017.1336709 
Dani, D. (2011). Sustainability as a framework for analyzing socioscientific issues. International Electronic Journal of Environmental Education, 1(2), 113-128.

Elfeky, A. I. M. (2018). The effect of personal learning environments on participants' higher order thinking skills and satisfaction. Innovations in Education and Teaching International, 1-12. https://doi.org/10.1080/14703297.2018.1534601

Fitzpatrick, B., \& Schulz, H. (2015). Do curriculum outcomes and assessment activities in science encourage higher order thinking? Canadian Journal of Science, Mathematics and Technology Education, 15(2), 136-154. https://doi.org/10.1080/14926156.2015.1014074

Goldman, D., Pe'er, S., \& Yavetz, B. (2017). Environmental literacy of youth movement members-is environmentalism a component of their social activism? Environmental Education Research, 23(4), 486-514. https://doi.org/10.1080/13504622.2015.1108390

Husamah, H., Fatmawati, D., \& Setyawan, D. (2018). OIDDE learning model: Improving higher order thinking skills of biology teacher candidates. International Journal of Instruction, 11(2), 249-264. https://doi.org/10.12973/iji.2018.11217a

Ichsan, I. Z., \& Rahmayanti, H. (2020). HOTSEP: Revised Anderson's taxonomy in environmental learning of COVID-19. European Journal of Educational Research, 9(3), 1257-1265. https:// doi.org/10.12973/eu-jer.9.3.1257

Ichsan, I. Z., Sigit, D. V., Miarsyah, M., Ali, A., Arif, W. P., \& Prayitno, T. A. (2019). HOTS-AEP: Higher order thinking skills from elementary to master students in environmental learning. European Journal of Educational Research, 8(4), 935-942. https://oi.org/10.12973/ eu-jer.8.4.935

Ichsan, I. Z., Sigit, D. V., Miarsyah, M., Ali, A., Suwandi, T., \& Titin, T. (2020). Implementation supplementary book of green consumerism: improving students hots in environmental learning. European Journal of Educational Research, 9(1), 227-237. https:/doi.org/10.12973/ eu-jer.9.1.227

Istiyono, E., Dwandaru, W. S. B., Setiawan, R., \& Megawati, I. (2020). Developing of computerized adaptive testing to measure physics higher order thinking skills of senior high school students and its feasibility of use. European Journal of Educational Research, 9(1), 91-101. https://doi. org/10.12973/eu-jer.9.1.91

Jiang, B., Yang, J., Lv, Z., Tian, K., Meng, Q., \& Yan, Y. (2017). Internet cross-media retrieval based on deep learning. Journal of Visual Communication and Image Representation, 48, 356-366. https://doi.org/10.1016/j.jvcir.2017.02.011

Kinslow, A. T., Sadler, T. D., \& Nguyen, H. T. (2018). Socio-scientific reasoning and environmental literacy in a field-based ecology class. Environmental Education Research, 4622, 1-23. https:// doi.org/10.1080/13504622.2018.1442418

Lee, A. Y. L. (2016). Media education in the school 2.0 era: Teaching media literacy through laptop computers and iPads. Global Media and China, 1(4), 435-449. https://doi. org/10.1177/2059436416667129

Lince, R. (2016). Creative thinking ability to increase student mathematical of junior high school by applying models numbered heads together. Journal of Education and Practice, 7(6), 206-212. 
Marzano, R. J., \& Kendall, J. S. (2006). The new taxonomy of educational objectives. Corwin Press. Mendhurwar, S., \& Mishra, R. (2018). Emerging synergies between Internet of things and social technologies. Journal of Global Information Technology Management, 21(2), 75-80. https:// doi.org/10.1080/1097198X.2018.1462918

Miarsyah, M., Rusdi, R., Aryani, N. D., \& Ichsan, I. Z. (2019). MEBA: Development android-based ecosystem module for senior high school students. Indian Journal of Public Health Research and Development, 10(8), 2114-2118. https://doi.org/10.5958/0976-5506.2019.02168.5

Morganti, L., Pallavicini, F., Cadel, E., Candelieri, A., Archetti, F., \& Mantovani, F. (2017). Gaming for Earth: Serious games and gamification to engage consumers in pro-environmental behaviours for energy efficiency. Energy Research and Social Science, 29(April), 95-102. https:// doi.org/10.1016/j.erss.2017.05.001

Motallebzadeh, K., Ahmadi, F., \& Hosseinnia, M. (2018). Relationship between 21st century skills, speaking and writing skills: A structural equation modelling approach. International Journal of Instruction, 11(3), 265-276. https://doi.org/10.12973/iji.2018.11319a

Paristiowati, M., Hadinugrahaningsih, T., Purwanto, A., \& Karyadi, P. A. (2019). Analysis of students' scientific literacy in contextual-flipped classroom learning on acid-base topic. Journal of Physics: Conference Series, 1156(1), 012026. https://doi.org/10.1088/1742-6596/1156/1/012026

Purwanto, A., Ichsan, I. Z., Gomes, P. W. P., Rahman, M. M., \& Irwandani, I. (2020). ESBOR during COVID-19: Analysis students attitude for develop 21st century environmental learning. Journal of Sustainability Science and Management, 15(7), 20-29. https://doi.org/10.46754/ jssm.2020.10.003

Quieng, M. C., Lim, P. P., \& Lucas, M. R. D. (2015). 21st century-based soft skills: spotlight on non-cognitive skills in a cognitive-laden dentistry program. European Journal of Contemporary Education, 11(1), 72-81. https://doi.org/10.13187/ejced.2015.11.72

Rahmayanti, H., Maulida, E., \& Kamayana, E. (2019). The role of sustainable urban building in industry 4.0. Journal of Physics: Conference Series, 1387(1), 012050. https://doi.org/10.1088/17426596/1387/1/012050

Rahmayanti, H., Oktaviani, V., \& Syani, Y. (2020). Development of sorting waste game android based for early childhood in environmental education. Journal of Physics: Conference Series, 1434(1), 012029. https://doi.org/10.1088/1742-6596/1434/1/012029

Reyna, J., Hanham, J., \& Meier, P. (2018). The Internet explosion, digital media principles and implications to communicate effectively in the digital space. E-Learning and Digital Media, 15(1), 36-52. https://doi.org/10.1177/2042753018754361

Reyna, J., Hanham, J., \& Meier, P. C. (2019). A framework for digital media literacies for teaching and learning in higher education. E-Learning and Digital Media, 15(4), 176-190. https://doi. org/10.1177/2042753018784952

Ritter, S. M., \& Mostert, N. (2017). Enhancement of creative thinking skills using a cognitive-based creativity training. Journal of Cognitive Enhancement, 1(3), 243-253. https://doi.org/10.1007/ s41465-016-0002-3 
Sahronih, S., Purwanto, A., \& Sumantri, M. S. (2019). The effect of interactive learning media on students' science learning outcomes. ACM International Conference Proceeding Series, 20-24. https://doi.org/10.1145/3323771.3323797

Sarkar, M., \& Corrigan, D. (2014). Promotion of scientific literacy: Bangladeshi teachers' perspectives and practices. Research in Science and Technological Education, 32(2), 162-181. https://doi.org/10.1080/02635143.2014.905462

Sigit, D. V., Azrai, E. P., Heryanti, E., Ichsan, I. Z., Jajomi, Y. P., \& Fadrikal, R. (2019). Development green consumerism e-book for undergraduate students (gc-ebus) as learning media in environmental learning. Indian Journal of Public Health Research and Development, 10(8), 2026-2031. https://doi.org/10.5958/0976-5506.2019.02152.1

Sigit, D. V., Miarsyah, M., Komala, R., Suryanda, A., Ichsan, I. Z., \& Fadrikal, R. (2020). EECN: Analysis, potency, benefit for students knowledge and attitude to conserve mangroves and coral reefs. International Journal of Instruction, 13(1), 125-138. https://doi.org/10.29333/ iji.2020.1318a

Smith, T. (2014). Elementary science instruction: Examining a virtual environment for evidence of learning, engagement, and 21st century competencies. Education Sciences, 4(1), 122-138. https://doi.org/10.3390/educsci4010122

So, W. W. M., Chen, Y., \& Wan, Z. H. (2019). Multimedia e-learning and self-regulated science learning: A study of primary school learners' experiences and perceptions. Journal of Science Education and Technology, 28(5), 508-522. https://doi.org/10.1007/s10956-019-09782-y

Suwono, H., Pratiwi, H. E., Susanto, H., \& Susilo, H. (2017). Enhancement of students' biological literacy and critical thinking of biology through socio-biological case-based learning. Jurnal Pendidikan IPA Indonesia, 6(2), 213-222. https://doi.org/10.15294/jpii.v6i2.9622

Talmi, I., Hazzan, O., \& Katz, R. (2018). Intrinsic motivation and 21st-century skills in an undergraduate engineering project: The formula student project. Higher Education Studies, 8(4), 46. https://doi.org/10.5539/hes.v8n4p46

Tanujaya, B. (2016). Development of an instrument to measure higher order thinking skills in senior high school mathematics instruction. Journal of Education and Practice, 7(21), 144-148.

Tanujaya, B., Mumu, J., \& Margono, G. (2017). The relationship between higher order thinking skills and academic performance of student in mathematics instruction. International Education Studies, 10(11), 78-85. https://doi.org/10.5539/ies.v10n11p78

Urbani, J. M., Truesdell, E., Urbani, J. M., Roshandel, S., Michaels, R., \& Truesdell, E. (2017). Developing and modeling 21st-century skills with preservice teachers. Teacher Education Quarterly, 44(4), 27-51.

Vidergor, H. E. (2018). Effectiveness of the multidimensional curriculum model in developing higher-order thinking skills in elementary and secondary students. The Curriculum Journal, 29(1), 95-115. https://doi.org/10.1080/09585176.2017.1318771

Yeung, S. yin S. (2015). Conception of teaching higher order thinking: perspectives of Chinese teachers in Hong Kong. Curriculum Journal, 26(4), 553-578. https://doi.org/10.1080/09585176. 2015.1053818 
Yusop, F. D., \& Sumari, M. (2013). The use of social media technologies among Malaysian youth. Procedia - Social and Behavioral Sciences, 103, 1204-1209. https://doi.org/10.1016/j. sbspro.2013.10.448

Zohar, A., \& Agmon, V. A. (2018). Raising test scores vs. teaching higher order thinking (hot): senior science teachers' views on how several concurrent policies affect classroom practices. Research in Science and Technological Education, 36(2), 243-260. https://doi.org/10.1080/ 02635143.2017.1395332

\title{
Mąstymo lygis švietime: išsami Andersono taksonomijos peržiūra
}

\author{
Ilmi Zajuli Ichsan ${ }^{1^{*}}$, Henita Rahmayanti ${ }^{2}$, Agung Purwanto ${ }^{3}$, Diana Vivanti Sigit ${ }^{4}$, \\ Edi Kurniawan ${ }^{5}$, Ardyanto Tanjung ${ }^{6}$, Ruqiah Ganda Putri Panjaitan ${ }^{7}$, Nurlita Pertiwi ${ }^{8}$, \\ Charanjit Kaur Swaran Singh ${ }^{9}$
}

\footnotetext{
Džakartos valstybinis universitetas, Rawamangun Muka g., ID-13220 Džakarta, Indonezija, ilmizajuli95@gmail.com Džakartos valstybinis universitetas, Rawamangun Muka g., ID-13220 Džakarta, Indonezija, henita.rahmayanti@ unj.ac.id

3 Džakartos valstybinis universitetas, Rawamangun Muka g., ID-13220 Džakarta, Indonezija, agungpurwanto@unj.ac.id

4 Džakartos valstybinis universitetas, Rawamangun Muka g., ID-13220 Džakarta, Indonezija, dianav@unj.ac.id

5 Semarango valstybinis universitetas, Sekaran Gunungpati, ID-50229 Semarangas, Indonezija, edikurniawan@mail. unnes.ac.id.

6 Valstybinis Malango universitetas, Semarangas, Malango g. 5, ID-65145 Malangas, Indonezija, ardyanto.tanjung.fis@ um.ac.id

Tanjungpuro universitetas, Jenderal Ahmad Yani g., ID-78124 Pontianakas, Indonezija, ruqiah.gpp@fkip.untan.ac.id

8 Makasaro valstybinis universitetas, A P Pettarani g., ID-90222 Makasaras, Indonezija, nurlita.pertiwi@unm.ac.id

$9 \quad$ Sultono Idris universitetas, Tanjong Malim, MY-35900 Malaizija, charanjit@fbk.upsi.edu.my
}

\section{Santrauka}

Tyrimo, kuris buvo atliktas 2020 m. liepos-rugpjūčio mẻn., tikslas - patikslinti Andersono taksonomiją ir igyvendinti naują taksonomiją. Tyrime buvo naudojamas aprašomasis metodas. I bendrą imtį pateko 1030 universiteto studentų, vidurinès mokyklos jaunesniųjų ir vyresniųjų klasių mokinių iš įvairių Indonezijos miestų. Naudoti 6 matavimo instrumentų tipai: aplinkosaugos žinios universitete; gamtos mokslų žinios universitete; socialinių mokslų žinios universitete; aplinkosaugos žinios mokykloje; gamtos mokslų žinios mokykloje; socialinių mokslų žinios mokykloje. Naująją taksonomiją sudarė 6 mąstymo lygiai: nustatymas, palyginimas, igyvendinimas, problemų suvokimas, problemų sprendimas ir naujovių plètojimas. Rezultatai parodè, kad studentų žinių balai vis dar buvo žemi: aplinkosaugos žinios universitete (34,85); gamtos mokslų žinios universitete $(34,90)$; socialinių mokslų žinios universitete $(36,52)$; aplinkosaugos žinios mokykloje (jaunesniųjų 30,21 ir vyresniųjų 34,72), gamtos mokslų žinios mokykloje (jaunesniųjų 31,29 ir vyresniųjų 36,46), 
socialinių mokslų žinios mokykloje ( jaunesniųjų 33,92 ir vyresniųjų 36,00). Nustatyta, kad studentų ir mokinių žinias dar reikia tobulinti ịvairiomis švietimo naujovėmis. Tyrimo metu buvo sukurta nauja taksonomija, o jos iggyvendinimas parodẻ, kad studentų ir mokinių žinių balas vis dar labai žemas, matuojant pagal mąstymo lygị naujoje taksonomijoje, todèl studentų ir mokinių balą reikia gerinti diegiant ịvairias švietimo naujoves.

Esminiai žodžiai: švietimas, nauja taksonomija, mąstymo lygis.

Gauta 20201123 / Received 23112020

Priimta 20210326 / Accepted 26032021 